\title{
Vapauttaa vai valtauttaa?
}

\asvatuksen ja koulutuksenkin käytännöt muuttuvat. Ainakin muut\uu kieli, jota työssämme käytämme. Harvassa opetussuunnitelmassa esimerkiksi enää käytetään termiä päätekäyttäytyminen tai vannotaan bloomilaisten tavoitetaksonomioiden nimeen. Onko kysymyksessä kasvatusta tutkivien tieteiden syvällisestä paradigman muutoksesta, joka heijastuu käytännön puhetapaan ja toimintaan, vai muodista, jonka mukana sekä tutkijat että kouluttajat juoksevat. Miten oppimisteorioiden muutos ja käytetty kieli behaviorismista kognitivismin kautta konstruktivismiin näkyy käytännön opetustyössä? Kirjoittavatko tutkijat vain toisilleen? Pakottaako meritoitumiskilpailussa menestyminen rakentamaan käsitteitä, jotka eivät kiinnity todellisuuteen tai ovat itse asiassa vain uusia nimilappuja vanhoille ja tutuille ilmiöille? Toisaalta taas säilytetään termejä, jotka kuuluvat jo hylättyyn käsitejärjestelmään ja kontekstiin, niitä uudelleen tulkiten ja virtaviivaistaen. Kvalifikaatio on esimerkki tästä. Sekä uudistermit että poikkeavasti käytetyt vanhat ja turvalliset aiheuttavat hämmennystä valveutuneessakin lukijassa, jonka työn kuvaan ei kuulu jatkuva käsiteanalyysi.

$\mathrm{K}$

ritiikistäni huolimatta tarjoan pohdittavaksi 1990-luvun muotiterutua, vahvistua ja voimistua tai transitiiviverbiksi valtauttaa, voimistaa, vahvistaa. Jo tämä erilainen kääntäminen kuvastaa kirjoittajan suhdetta ilmiöön. Käsite on syntynyt yhteisöpsykologian ja antropologisen toimintatutkimuksen piirissä ja erityisesti sitä on käytetty sosiaalisten ohjelmien ja interventioiden toimeenpanon tutkimiseen ja tulosten arviointiin. Tavallisesti käsite kytketään yksilön valtautumiseen, mutta yhtä hyvin sitä voidaan käyttää organisaation tai yhteisön itseohjautuvuuden, itsemääräämisoikeuden ja itsekunnioituksen hankkimisen ymmärtämiseen ja hankkimiseen. Kysymyksessä on toimijoiden auttaminen auttamaan itseään. Tarvitaan siis valmentajaa, animaattoria, fasilitaattoria katalysaattoriksi ja tukijaksi ja valtauttajaksi, mutta ennen kaikkea välineitä omille valtautumispyrkimyksille. Suomenkielisen termin löytäminen on tästä syystä vaikeaa.

$\mathrm{V}_{\mathrm{e}}$ altautuminen on pitkä prosessi, kuin viestijuoksu, jossa yhden osuuden epäonnistuminen turmelee koko juoksun tuloksen. Jo Paolo Freire korosti omien tarpeiden tunnistamisen ja ilmaisemisen tärkeyttä ihmisen kasvulle. Tarpeiden tyydyttämiseksi on asetettava tavoitteet tai ilmaistava odotuksensa ja toiveensa. On työstettävä suunnitelma tavoitteisiin pääse- 
miseksi. Tavoitteiden saavuttamiseen tarvitaan sekä aineellisia että aineettomia välineitä, voimavaroja, ja niiden hankkiminen pakottaa toimintaympäristön näkemiseen omien tavoitteiden saavuttamista edistävänä tai estävänä tekijänä. Olennaista on kuitenkin usko, että siihen voi vaikuttaa. Ketjun päättää kyky arvioida omaa toimintaansa tavoitteittensa saavuttamisen näkökulmasta ja tämän palautteen käyttö toiminnan ohjaamiseen. Nykykieli puhuu reflektiosta.

$\mathrm{V}$

alistunut lukija kysyy, eikö edellisen vuosikymmenen termi "emansipaatio" sovi tähän käyttöön. Kyllä ja ei! Käsitteet viittaavat samaan kohteeseen, mutta eivät peitä sitä samalla tavalla. Vapautumiseen ja valtautumiseen liittyy valta, joka sisältyy sekä empower-käsitteen nimilappuun että sisältöön. Jos valta tuottaa virallisen totuuden, voiko vallasta riippumatonta totuutta silloin olla? Mihin pitäisi valtautua, totuuteenko vai vallankäyttöön? Habermas edustaa kommunikatiivisessa etiikassaan näkemystä, että vallasta riippumaton ihmisten välinen viestintä on mahdollista. Foucault näkee vallan olevan toimijoiden ulkopuolella ja kaikkialla rakenteissa, niin että sen minkä tiedämme, tiedämme vallan suodattamana. Valtautumisen ja emansipaation käsitteillä voimme säilyttää tämän eron. Valtautuminen merkitsisi toimimista menestyksellisesti olemassa olevissa valtarakenteissa, niissä äänen hankkimista ja niiden käyttämistä omien tavoitteiden ajamiseen. Emansipaatio pyrkii muuttamaan valtarakenteita ja haastamaan vallanpitäjien oikeutuksen vallankäyttöön. Eron tekemisellä vältetään monta oppiriitaa oppineiden välillä, mutta oppilaitoksen toiminnalle erolla on myös merkitystä. Vaikka pitäisimmekin koulutusta durkheimilaisittain keskeisenä säilyttävänä instituutiona, vaikea on valtauttavaa opetussuunnitelmaa vastaan protestoida. Emansipoiva opetussuunnitelma on paljon helpompi värittää (puolue)poliittiseksi.

\section{Reijo Raivola}

